\title{
卵白アルブミン溶液のケイ光スペクトルについて
}

\author{
守康則 \\ 広島大学教育学部福山分校
}

\section{Fluorescence Spectrum of Ovalbumin Solution}

\author{
Yasunori Mori \\ Fukuyama Branch, Faculty of Education, Univ. of Hiroshima
}

J. Jap. Soc. Food and Nutr., 25 (7), 525 531 (1972)

In order to get a clue to detect the change of protein structure by degradation, the fluorescence spectra of the aqeous ovalbumin solution were estimated in relation to the denaturation of protein by temperature, acid $(\mathrm{pH})$, light illumination, urea and guanigin-hydrochloride, and the browning of protein with glucose and xylose.

The maximum increase of the fluorescence intensity of the ovalbumin was observed at the first stage of the thermal treatment $(1-5$ minutes $)$ at $60^{\circ} \mathrm{C}$. Its thermal increase of the fluorescence intensity was highest at $\mathrm{Tyr}$ residue spectrum. The fluorescence intensity of the ovalbumin was heigher between neutrality and alkaline region ( $\mathrm{pH} 10)$ and lower at the acidic $\mathrm{pH}$ region, expecially, the maximum decrease of fluorescence intensity was observed at both $\mathrm{pH} 4.0$ and $\mathrm{pH} 12$. The increase of fluorescence of the ovalbumin were observed at Try residue at the first stage of ultra viollet rays illumination in the presence of riboflavin, and then its fluorescence intensity was remarkably decreased with illumination time.

The maximum decrease of the fluorescence intensity of ovalbumin with urea (8 $M)$ and guanidinhydrochloride $(0.4 \mathrm{M})$ was observed at $\mathrm{Tyr}$ and Try residue. The quenching effect of fluorescence intensity by guanidin-hydrochloride were greater than that of urea.

The maximum increase of the fluorescence of the ovalbumin with glucose and xylose was observed at the first stage of the browning reaction ( 4 days) and then diminished accompanying elevation the browning of the protein.

(Received April 13, 1972)

たん白質溶液は一般に 250 ～320 $\mathrm{m} \mu$ 間のいずれかの 波長で励起すると，その波長に応じてトリプトファン (Try), チロシン (Tyr), フェニルアラニン (Phe) 残

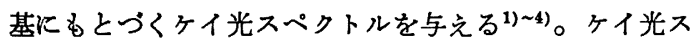
ペクトルにおける極大の位置およびケイ光の量子収量は たん白質の種類によって異なるが，たん白質分子のヶ イ光は，たん白質の構造と密接な関係をもち，Try， Tyr，Phe などケイ光性アミノ酸残基のたんばく質分子 内部での存在状態に鋭敏に左右されるので適当な実験方 法と解析手段を用いると，紫外部吸収スペクトルと同様 に変性なとによるたんばく質分子の内部構造の变化の解 明の強力な手段となりらる。事実，たんばく質分子構造 とケイ光との関係については比較的多くの報文がみら れ, Cowgill はとくにヘリックス構造 (Helical confor- mation）をもつ筋肉たん白質 meromyosin ${ }^{5}$ ， paramyo$\sin ^{6)}$ さらにリボヌクレアーゼ $\mathrm{A}^{7)}$ にいて尿素变性, 熱 変性, 酸变性, イオン強度などの環境变化に基づくへリ ックスの変化, トリプシン消化によるヘリックスの崩壊 をもとにヶイ光との関係を追究し，たん白質分子のへリ ックスのランダムコイルの変化は Try, Tyr のケイ光強 度の減少や消光をもたらし，たん白質のヶイ光はたん白 質の構造変化を知る上の実験的尺度となりらることを指 摘している。太田ら ${ }^{8)}$ も酵母のアルコール脱水素酵素に ついて，また Kaplan ら99はアルコール脱水素酵素括 よび乳酸脱水素䣼素について，それぞれ尿素変性，熱変 性に際しての酵素のケイ半強度の減少と酵素たん白質の ヘリックスの unfolding とが密接な関係をもつことを示 唆している。 
これらの見地よりたん白質の変性や劣化にともならた 几白質構造の微細な変化を知る方法の一つとしてヶイ光 スペクトルの変化に注目し，卵白アルブミン水溶液を試 料として尿素，熱， $\mathrm{pH}$ ，光などによるたん白質の变性と ケイ光スペクトルの関係，さらにグルコースおよびキシ ローズとたん白質との褐変化とケイ光スペクトルとの関 係を追究した。なお本実験と並行してたん白質变性度を SH 基について Ellman 法10)に基ついて測定したが，本 実験の卵白アルブミン濃度において，濃度が希薄なため SH 基の測定はできなかった。

\section{実 験 方 法}

卵白アルブミン溶液：卵白アルブミン（メルク製）を 用い，水あるいは $0.1 \mathrm{M}$ クエン酸・リン酸ナトリウム 緩衝夜， $0.1 \mathrm{M}$ クエン酸ナトリウム・塩酸緩衝液にそれ ぞれ溶解し，0.05\%溶液として実験に供した。

ケイ光スペクトルの測定：ケイ光スペクトルは島津 製自記ケイ光分光光度計 GSF-16 型を用い，励起波長 $280 \mathrm{~m} \mu$ にてケイ光スペクトルを求め, ケイ光強度はケ イ光エネルギーの相対值（R.E）をむって示した。なお 実験結果図表中に示す coarse 扎よび fine の number は, ケイ光分光光度計の直流増幅器の感度段階を表わす 数値である。

実験結果および考察

1. 卵白アルブミンおよび芳香族アミノ酸のケイ光ス ペクトル

0. 05\%卵白アルブミン水溶液および $0.05 \%$ Try, Tyr, Phe 水溶液のケイ光スペクトルを求めた。結果は Fig.
1-1 に示されるごとく卵白アルブミン水溶液 $(\mathrm{pH}$ 6.8)は $285 \mathrm{~m} \mu, 340 \mathrm{~m} \mu, 570 \mathrm{~m} \mu$ および $660 \mathrm{~m} \mu$ にそれぞれ $\lambda_{\max }$ を示した。Phe, Tyr, Try のそれぞれの芳香族ア ミノ酸のケイ光スペクトルはFig. 1-2 に示されるごとく Phe は $290 \mathrm{~m} \mu, 560 \mathrm{~m} \mu$ に, Tyr は $305 \mathrm{~m} \mu$ と $595 \mathrm{~m} \mu$ に, Tryは $360 \mathrm{~m} \mu, 680 \mathrm{~m} \mu$ に $\lambda_{\max }$ がみとめられる。 Phe のケイ光強度はTyr およびTryに比較してきわめ て小さい。たん白質のケイ光強度はそれに含まれるケイ 光性アミノ酸 (Phe, Tyr, Try) の配位状態に左右される ため，これらのアミノ酸の含量とは必ずしも比例せず， 波長も単独のアミノ酸とは若干ずれる場合が多い11。

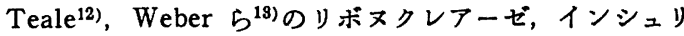
ンおよび球状たん白質のケイ光強度と $\lambda_{\max }$ に関する実 験結果より一般にケイ光アミノ酸を 2 種以上含むたん 白質分子はケイ光の $\lambda_{\max }$ の位置が単独アミノ酸溶液の 場合より短波長側へ shift することが示唆されている。 Weber らの実験結果を参照し，Fig. 1-1 亿示される卵白 アルブミンのケイ光スペクトルにおいて $285 \mathrm{~m} \mu$ と 570 $\mathrm{m} \mu$ に $\lambda_{\max }$ をるつものは Tyr 残基に, $340 \mathrm{~m} \mu$ と 660 $\mathrm{m} \mu$ に $\lambda_{\max }$ をるつるのは Try 残基によるすのと推考 される。

2. 卵白アルプミンのケイ光スベクトルと温度

$0.05 \%$ 卵白アルブミン水溶液 $10 \mathrm{~m} l$ を内径 $(18 \times 170$ $\mathrm{mm}$ ）の硬質無色試験管に入れ，暗所下に $60^{\circ} \mathrm{C}$ の小型 定温水槽に保持し, そのケイ光スペクトルの変動を経時 的に求めた。加熱温度は卵アルブミンの熱凝固性より $60^{\circ} \mathrm{C}$ を限度とした。また $0.05 \%$ の未変性卵白アルブミ ンのケイ光スペクトルをあわせ求め対照とした。結果は Fig. 2 に示されるごとく，とくに Tyr 残基 $\left(\lambda_{\max }: 285\right.$

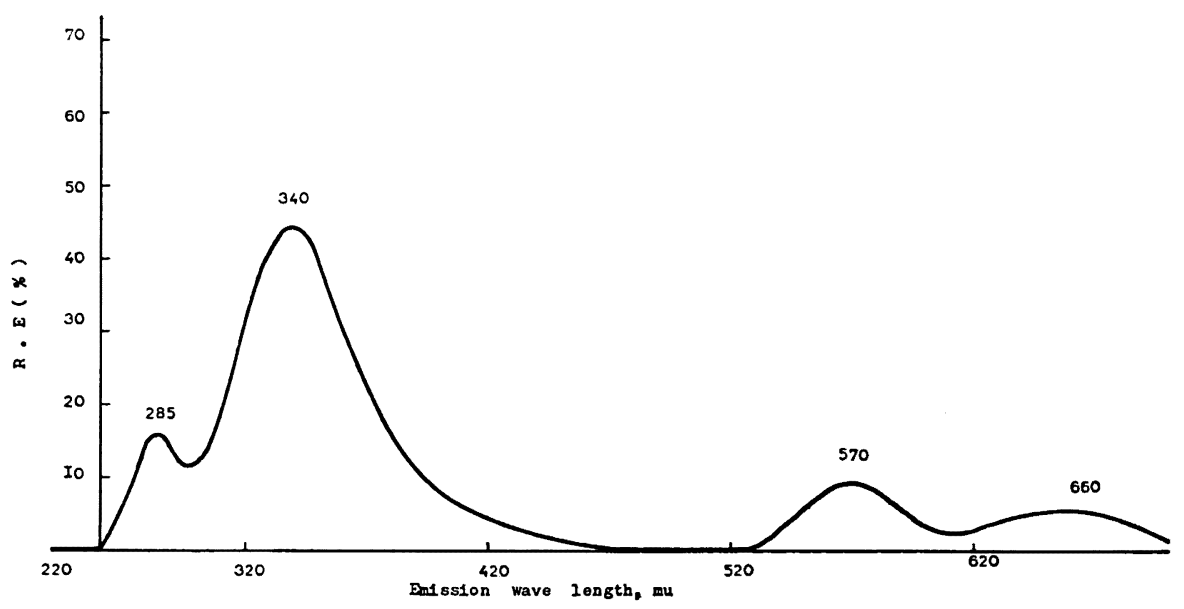

Fig. 1-1. Fluorescence spectrum of aqueous ovalbumin solution.

Excitation wave length : $280 \mathrm{~m} \mu, \mathrm{S}^{*}$ : coarse 5, fine 8 . $S^{*}$ (number of coarse and fine) shows the step of the sensitivity on the amplification meter of Shimazu spectro fluorometer GSF-16. 


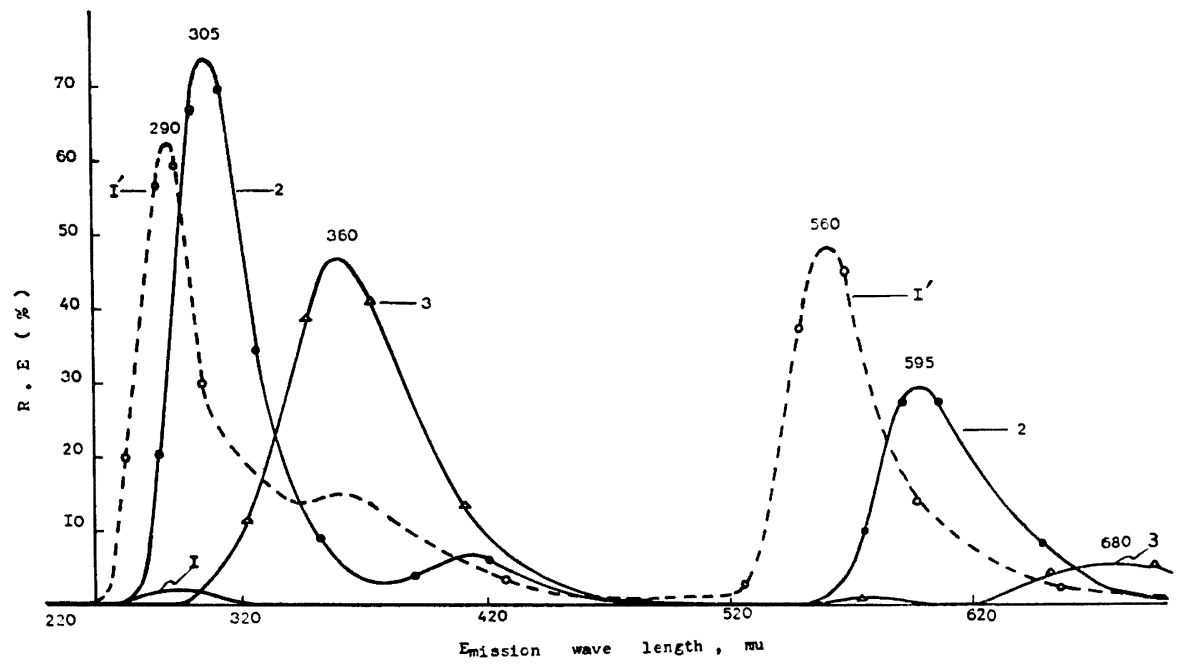

Fig. 1-2. Fluorescence spectrum of aqueous aromatic amino acid solution. curve 1 : Phe, curve 2 : Tyr, curve $3:$ Try, curve $1^{\prime}$ : Phe

Curve 1,2, 3 was assayed at excitation wave length $280 \mathrm{~m} \mu$ with coarse 6 , fine 8 and curve $1^{\prime}$ was assayed at excitation wave length $280 \mathrm{~m} \mu$ with coarse 10, fine 8 of the amplification meter.

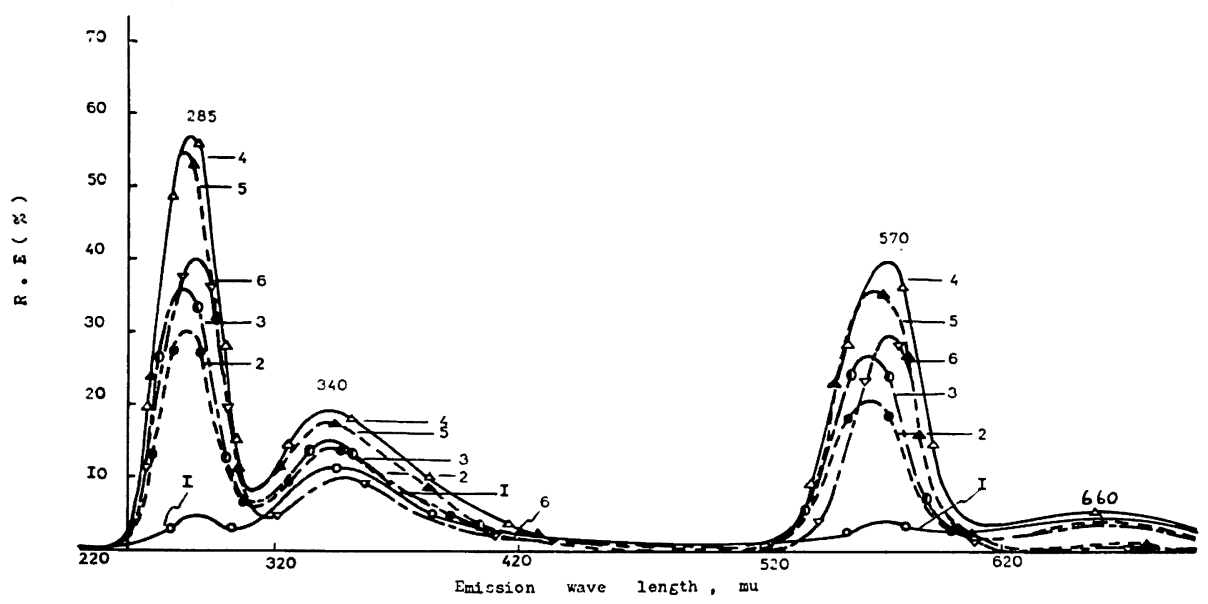

Fig. 2. Thermal dependence of the fluorescence spectrum for aqueous ovalbumin solution. curve $1: 0 \mathrm{~min}, 2: 1 \mathrm{~min}, 3: 5 \mathrm{~min}, 4: 15 \mathrm{~min}, 5: 30 \mathrm{~min}, 6: 1 \mathrm{hr}$.

Excitation wave length : $280 \mathrm{~m} \mu, \mathrm{S}:$ coarse 4 , fine 8 .

$\mathrm{m} \mu, 570 \mathrm{~m} \mu)$ において 1 分, 5 分, 15 分と比較的短時 間にヶイ光強度の急激な增加がみられ，その後は 30 分, 1 時間と加温時間とともにヶイ光強度の減少がみられ る。 $\operatorname{Try}$ 残基 $\left(\lambda_{\mathrm{max}}: 340 \mathrm{~m} \mu, 660 \mathrm{~m} \mu\right.$ ) \& Tyr 残基と ほぼ同様のケイ光スペクトルの変化がみとめられるが, ケイ光強度の変動は比較的小さい。これらの結果より温 度は卵白アルブミンの構造変化に著しい影響を与え， 反応初期のケイ光強度の増大はたん白質の高次構造の unfolding に基つく $\mathrm{Tyr}$ 残基, Try 残基のケイ光増大 によるものと考えられ, さらに加温 30 分後のケイ光強 度の減少は一度ほぐれた楧造が水素結合の再生などによ
り再びアトランダムに aggregation されるものと考えら れる。したがってたん白質溶液のケイ光強度は著しい温 度効果がみられ, ケイ光強度の観察は加熱によるたん白 質構造の微細な変化, 变性を検出する上の鋭敏な手段と なりらる。

\section{3. 卵白アルブミンのケイ光スペクトルと $\mathbf{p H}$}

卵白アルブミンのケイ光スペクトルの $\mathrm{pH}$ 依存性を卵

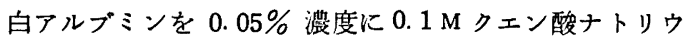
ム一塩酸緩衝液 ( $\mathrm{pH}$ 3.0 5.0 )，0.1 M-クエン酸ーリン酸 ナトリウム緩衝液に溶解し $\mathrm{pH}$ 3〜12 の範囲にて検討し た。結果は Fig. 3 に示されるごとくとくに Try 残基 


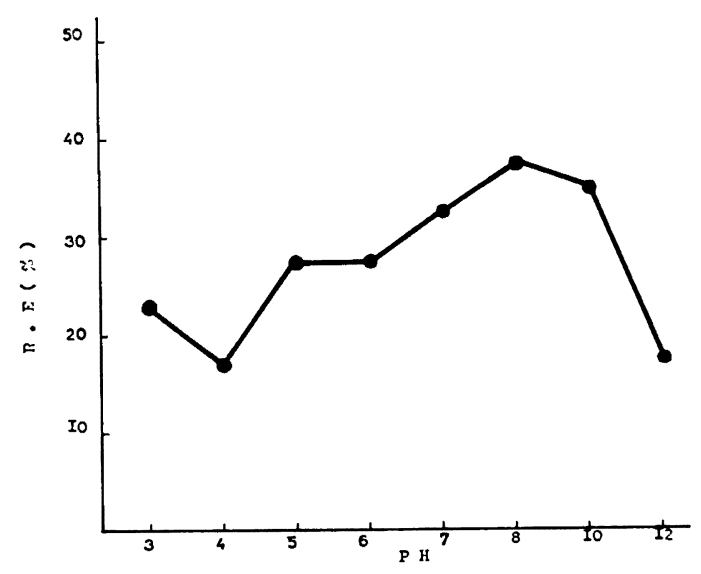

Fig. 3. The $\mathrm{pH}$ dependence of the fluorescence spectrum for ovalbumin.

R. E. was assayed at $340 \mathrm{~m} \mu$ emission wave length.

Excitation wave length : $280 \mathrm{~m} \mu, \mathrm{S}:$ coarse 7 , fine 8.

$\left(\lambda_{\max }: 340 \mathrm{~m} \mu\right)$ のケイ光強度についてみると全般的に 中性よりアルカリ性域（pH 10）においてケイ光強度は 高く, 酸性域においては pH の低下に伴って減少消光が みられる。な拈 $\mathrm{pH} 12.0$ の強アルカリ性域に拈いては ケイ光強度の著しい消光が注目される。White ${ }^{14)}$ す Try と Tyr および誘導体のケイ光量子収量に対する $\mathrm{pH} の$ 影響をしらべ，Try 括よび Tyr ともに酸性域において 減少消光すると報告している。

4. 卵白アルフミンのケイ光スペクトルと光照射

$0.05 \%$ 卵白アルブミン水溶液に光増感㓮としてリボフ
ラビン（反応液中の濃度 $10^{-5} \mathrm{M}$ ) を添加し, 内径 $(18 \times$ $170 \mathrm{~mm}$ ) の硬質無色の試験管に入れ, 室温 $\left(20^{\circ} \mathrm{C}\right)$ に て, 光源として $100 \mathrm{~V}, 15 \mathrm{~W} \times 2$ の紫外線殺菌灯を用 い, 光源より試験管までの距離 $4 \mathrm{~cm}$ にて照射処理を行 ない, 卵白アルブミンのケイ光スペクトルの変化を経時 的に求めた。結果はFig. 4 に示されるごとくケイ光スペ クトルの著しい変化を示し, Tyr 残基 $\left(\lambda_{\max }: 285 \mathrm{~m} \mu\right.$, $570 \mathrm{~m} \mu)$ および Try 残基 $\left(\lambda_{\max }: 340 \mathrm{~m} \mu, 660 \mathrm{~m} \mu\right)$ は 照射初期 30 分間はわずかにケイ光強度の增大を示すが, その後照射時間とともにケイ光強度の著しい減少がと められる。照射初期段階のケイ光強度の増大は加温処理 （実験結果 Fig. 2 参照）の場合と同様卵アルブミンの立 体構造が注ぐれケイ光性アミノ酸残基が遊離状態すしく は露出状態 (exposed state) に牧かれるためと推考さ れ，これらのアミノ酸残基もその後照射時間とともに光 分解をらけケイ光強度す著しく減少することが考えられ る。

5. 卵白アルプシンケイ光スペクトルと尿素および グアニジン処理効果

尿素および塩酸グアニジンを $0.05 \%$ 卵白アルブミン 水溶液に添加, 最終濃度尿素 $8 \mathrm{M}$, 塩酸グアニジン 0.4 $\mathrm{M}$ とし, $37^{\circ} \mathrm{C}$ にて反応せしめ, 卵白アルブミンのケイ 光スペクトルの変化を経時的に求めた。結果は Fig. 5-1 Fig. 5-2 に示されるごとく，尿素変性，グアニジン変 性ともに Tyr 残基 $\left(\lambda_{\max }: 285 \mathrm{~m} \mu, 570 \mathrm{~m} \mu\right)$ に执い て反応時間とともにケイ光強度の著しい減少がみられ， Try 残基 $\left(\lambda_{\max }: 340 \mathrm{~m} \mu, 660 \mathrm{~m} \mu\right)$ において子 Tyr 残 基と同様に全般的にケイ光強度の減少がみられる。なお

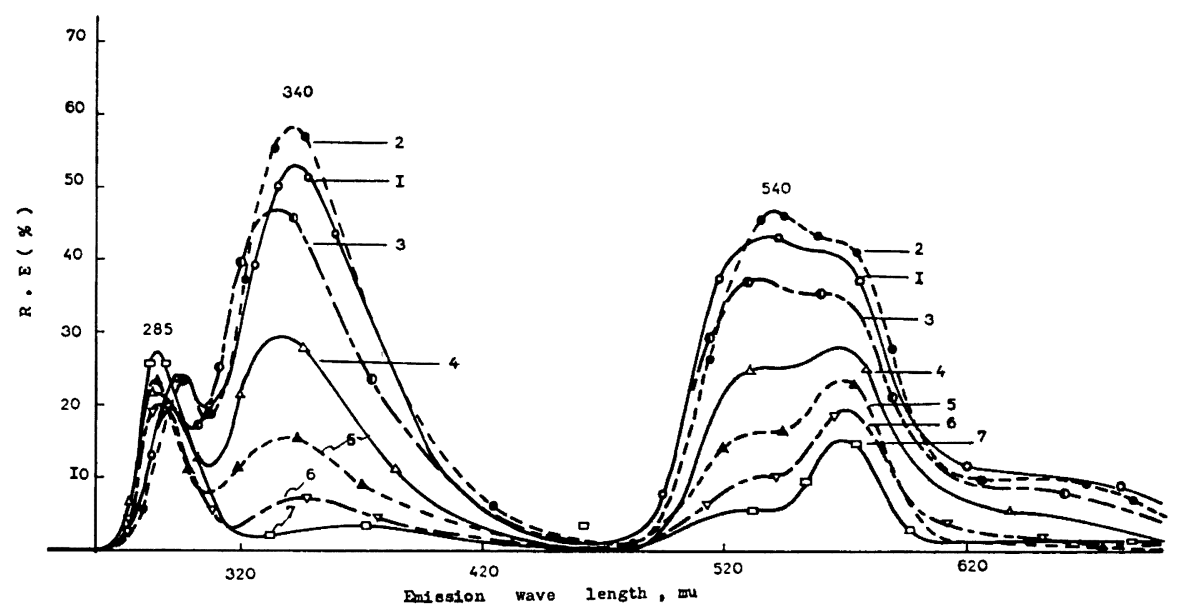

Fig. 4. Effect of the ultraviolet rays illumination on the fluorescence spectrum of ovalbumin in the presence of riboflavin.

Illumination time

curve $1: 0 \mathrm{~min}, 2: 30 \mathrm{~min}, 3: 1 \mathrm{hr}, 4: 2 \mathrm{hr}, 5: 4 \mathrm{hr}, 6: 6 \mathrm{hr}, 7: 8 \mathrm{hr}$, concn. of riboflavin : $10^{-5} \mathrm{M}$.

Excitation wave length : $280 \mathrm{~m} \mu, \mathrm{S}:$ coarse 6 , fine 5 . 


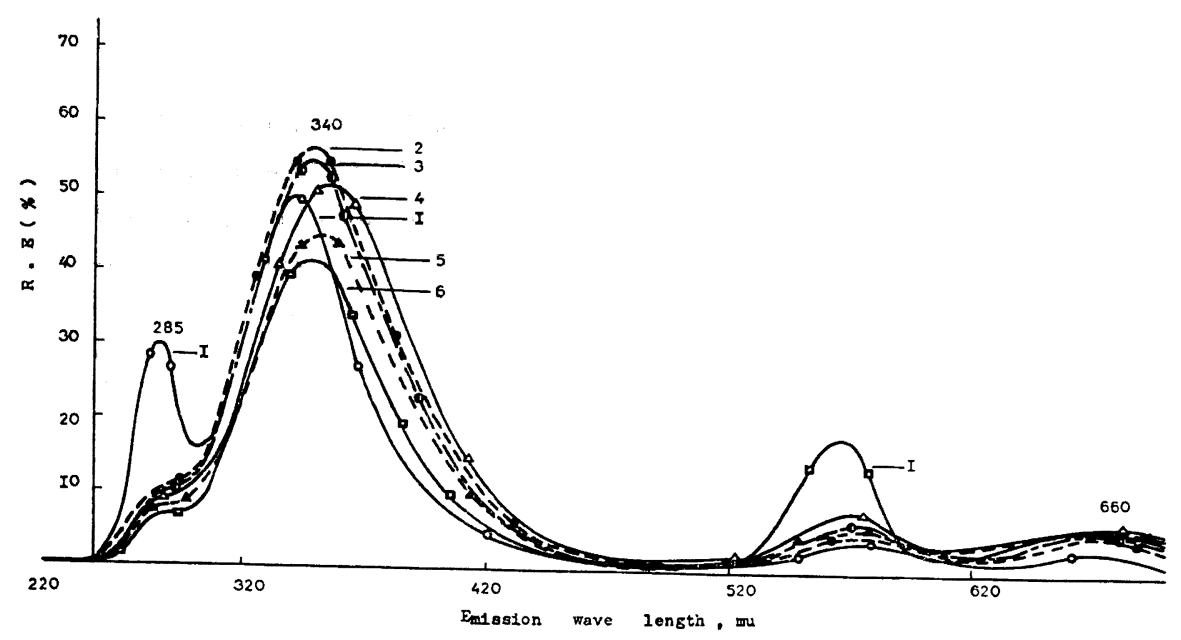

Fig. 5-1. Effect of urea on the fluorescence spectrum of ovalbumin. incubation time at $37^{\circ} \mathrm{C}, \mathrm{pH} 6.8$

Curve 1 : without urea, $2: 0 \mathrm{~min}, 3: 30 \mathrm{~min}, 4: 1 \mathrm{hr}, 5: 2 \mathrm{hr}, 6: 4 \mathrm{hr}$, concn. of urea : $8 \mathrm{M}$.

Excitation wave length : $280 \mathrm{~m} \mu, \mathrm{S}:$ coarse 7 , fine 5 .

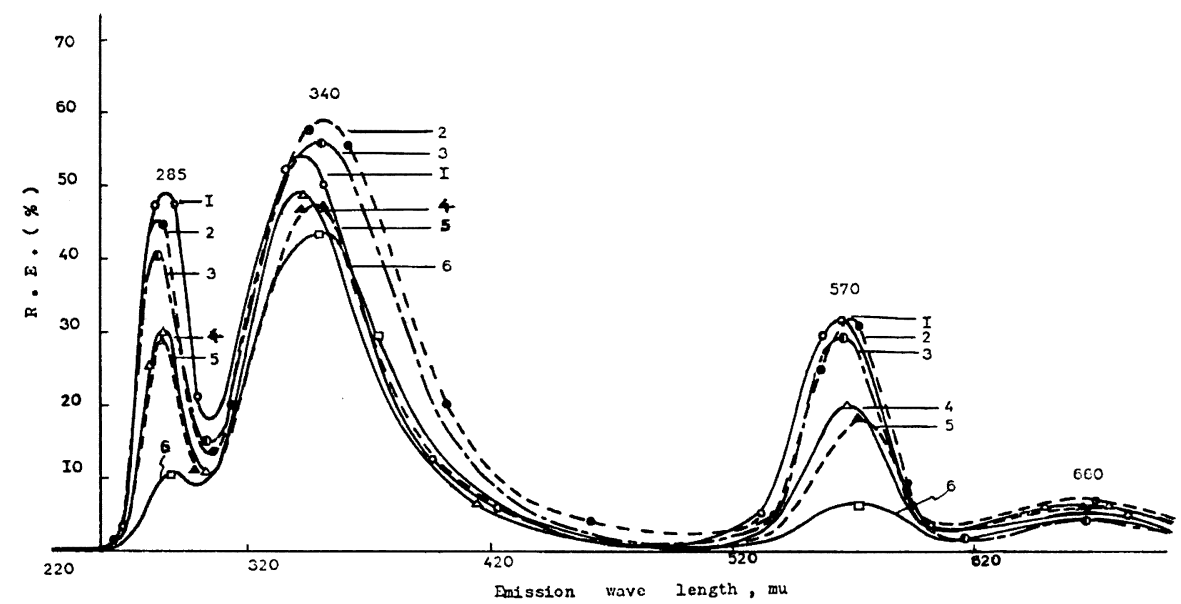

Fig. 5-2. Effect of guanidine hydrochloride on the fluorescence spectrum of ovalbumin. incubation time at $37^{\circ} \mathrm{C}$

Curve $1:$ without guanidine hydrochloride $2: 0 \mathrm{~min}, 3: 30 \mathrm{~min}, 4: 1 \mathrm{hr}$, $5: 2 \mathrm{hr}, 6: 4 \mathrm{hr}$, concn. of guanidine hydrochloride : $0.4 \mathrm{M}$.

Excitation wave length : $280 \mathrm{~m} \mu, \mathrm{S}:$ coarse 7 , fine 5 .

塩酸グアニジンは溶解度の関係より $0.4 \mathrm{M}$ 濃度にとどめ た。これらの結果より Tyr 残基のケイ光強度は Try 残 基よりる尿素, グアニジンによる影響をらけやすく，ま た同じモル濃度についてみると, 塩酸グアニジンが尿素 よりケイ光強度に著しい効果をすつことが推考される。 なお太田ら ${ }^{8)}$ 酵母のアルコール脱水素酵素について尿 素濃度の増大に伴って Tyr 残基に基つくく思われるケ イ光の減少を報告している。
6. 卵白アルフミンのケイ光スペクトルとたん白鹠褐 変化の効果

たん白質の遊離アミノ基は還元糖やカルボニル化合物 と反応し，反応の初期段階はたん白質の物理的性質は ほとんど変化はないが, 遊離基の $50 \%$ 以上が糖と結合 するとたん白質は褐变化し栄養価を低下する。糖一アミ ノ酸の褐変反応には必ずヶイ光が発生するが, ケイ光生 成機構およびケイ光性物質の本体については明らかでな 
い。Burton ら ${ }^{14)}$ は, ケイ光物質は不飽和カルボニル化 合物で,メラノイジンの中間体であると報告しており,ま た最近五明ら ${ }^{15)}$ はグリシンーキシローズ系より調製した メラノイジンの化学的性質について，メラノイジンは加 熱 $\left(90^{\circ} \mathrm{C}\right)$ によって解重合脱色がみられ, ケイ光は增大 し,ケイ光物質の生成を指摘している。これらの見地より アミノーカルボニル反応に拈けるヶい光反応は食品の褐 変化に拈いて重要視される。したがって卵白アルプミン のケイ光スペクトルに及ぼす糖-たん白質褐変化の影響
をしらべた。すなわちグルコース，キシロースを $0.05 \%$ 卵白アルプミン水溶液にそれぞれ添加，最終濃度 0.25 M にて $37^{\circ} \mathrm{C}$ に反応せしめ卵白アルプミンのケイ光スペ クトルの変化を経時的に求めた。結果はグルコースのと きはFig. 6-1 に示されるごとく Try 残基 $\left(\lambda_{\max }: 340\right.$ $\mathrm{m} \mu, 660 \mathrm{~m} \mu)$ については反応初期においては，わずか にヶイ光強度の減少を示すが 4 日目にヶイ光強度の急激 な増大が注目され, さらに褐変化の増大に伴ってその後 再び反応時間とともにケイ光強度は減少する。 Tyr 残基

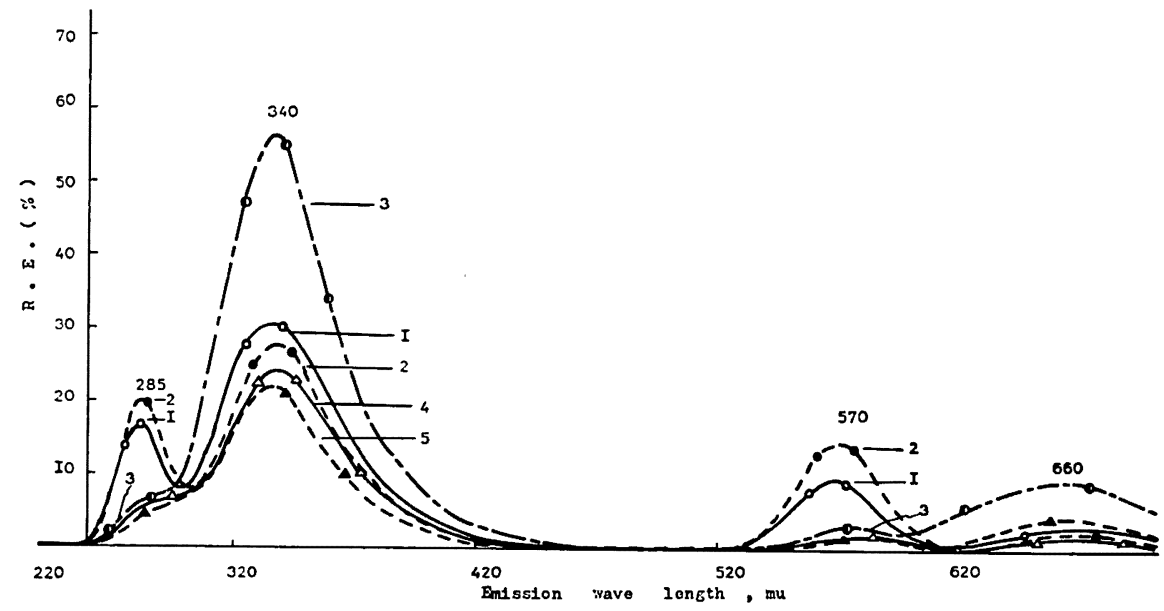

Fig. 6-1. The fluorescence spectrum of the browning ovalbumin with glucose. incubation time at $37^{\circ} \mathrm{C}$

Curve 1: 0 day (not browned), $2: 1$ day (not browned), $3: 4$ day (light brown), $4: 8$ day (brown), $5: 10$ day (brown), concn. of glucose : $2.5 \mathrm{M}$.

Excitation wave length : $280 \mathrm{~m} \mu, \mathrm{S}:$ coarse 6 , fine 5

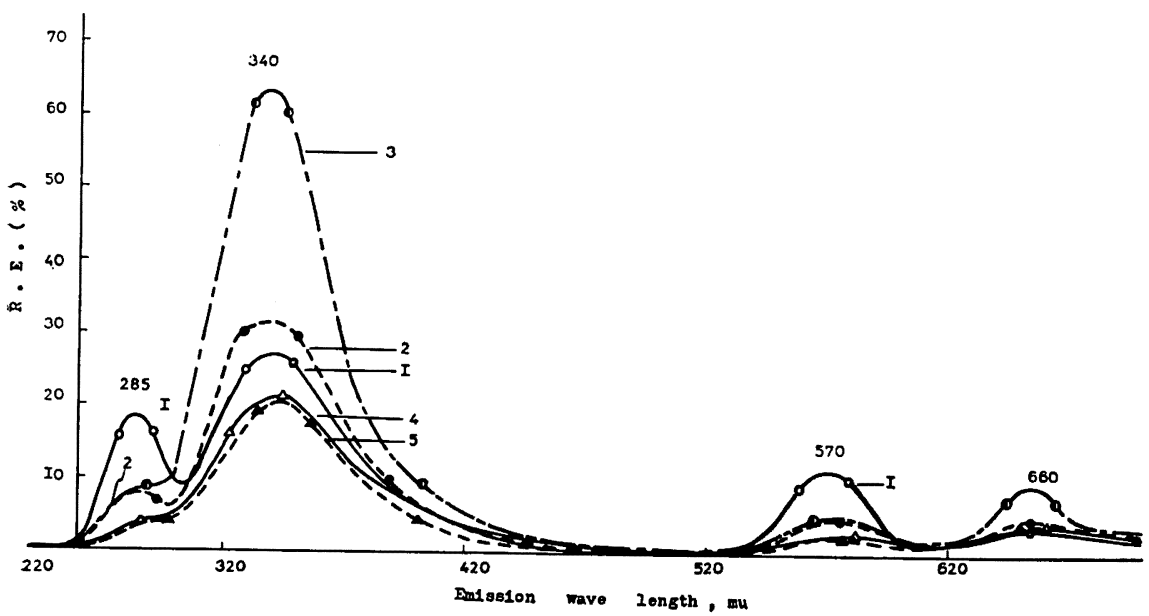

Fig. 6-2. The fluorescence spectrum of the browning ovalbumin with xylose. incubation time at $37^{\circ} \mathrm{C}$

Curve 1: 0 day (not browned), $2: 1$ day (not browned), $3: 4$ day (light brown), $4: 8$ day (brown), $5: 10$ day (brown), concn. of xylose : $2.5 \mathrm{M}$. Excitation wave length : $280 \mathrm{~m} \mu, \mathrm{S}$ : coarse 6, fine 5 . 
$\left(\lambda_{\max }: 285 \mathrm{~m} \mu, 570 \mathrm{~m} \mu\right)$ 飞扰いては反応 1 日目にケイ 光強度の増大がみられその後ケイ光強度は減少を示す。 キシロースのときは Fig. 6-2 に示されるごとくグルコ 一スのときとほぼ同様の結果がみられ，Try 残基につい ては反応 4 日目にヶイ光強度の著しい增大がみられ，褐 変化の増大に伴って再び反応時間とともにヶイ光強度は 減少を示す。これらの結果よりメラノイジンへの褐変化 の中間体に最も強いヶイ光反応がみとめられることが推 考される。

\section{要 約}

たん白質の変性や劣化に伴うたん白質分子構造の変化 をそのケイ光反応より知る目的から，卵白アルブミン水 溶夜について, 加熱, 酸 $(\mathrm{pH})$, 光照射, 尿素, 塩酸-グ アニジンを作用せしめ，たん白質の变性段階に抽けるケ イ光スペクトルの変動をしらべまた糖一たん白質の褐 変化に伴らケイ光スペクトルの変動をグルコースおよび キシャーズ・たん白質系についてしらべた。

1）卵白アルブミン水溶液は $60^{\circ} \mathrm{C}$ の温度処理におい て, 反応 1 5 分間の比較的短時間にヶイ光強度に急激 な增大がみられ，とくにチロシン残基に基づくケイ光強 度の上昇が著しい。

2）卵白アルブミンのケイ光強度は中性より $\mathrm{pH} 10$ のアルカリ性域に打いて増大し，酸性域に招いては pH の低下に伴って減少消光する。なお $\mathrm{pH} 12.0$ の強アル カリ性域においてはケイ光強度の減少がみられる。

3）リボフラビンの存在に执いて, 紫外線照射処理に より卵白アルブミンはトリプトファン残基，チロシン残 基ともに照射時間に伴ってケイ光強度の著しい減少がみ られる。

4）尿素（8M) 扎よび塩酸グアニジン $(0.4 \mathrm{M})$ は卵 白アルブミンのチロシン残基に基づくケイ光強度を著し く減少せしめ, 塩酸グアニジンは尿素に比較してケイ光
の消光効果が大きい。

5）卵白アルブミンはグルコース，キシローズとの褐 变反応 $\left(37^{\circ} \mathrm{C}, \mathrm{pH} \mathrm{6.0)}\right.$ 飞执いて褐变反応初期段階はケ イ光強度の急激な増大がみられ，その後褐变反応の進行 にともなってケイ光強度の減少がみとめられる。

これらの結果よりたん白質のケイ光スペクトル分析は たん白質の変性や劣化に伴らたん白質分子構造の微細な 変化を知る有力な手段となりうる。

本研究は堀川春代, 山岡雅子婹の協力に負らところが 大きい。ここに深謝の意を表する。

\section{文献}

1）太田ゆみ子，太田隆久，和田昭允：たんぱく質， 核酸, 醉素, 8, 362 (1963)

2) Steiner, R. F. and Edelhoch, H. : Biochem. Et. Biophys. Acta, 66, 341 (1963)

3) Weber, G. : Biochem. J., 75, 235 (1960)

4) Teale, F. : Biochem. J., 76, 381 (1960)

5) Cowgill, R. W. : Biochem. Et. Biophys. Acta, 163, 431 (1968)

6) Cowgill, R. W. : Biochem. Et. Biophys. Acta, 168, 417 (1968)

7) Cowgill, R. W. : Biochem. Et. Biophys. Acta, 120, 196 (1966)

8) Ohta, T. and Ogura, Y. : J. Biochem., 58, 73 (1965)

9) Brand, L., Everre, J. and Kaplan W. O. : Biochemistry, 1, 423 (1962)

10) Ellman, L. G. : Arch. Biochem. Biophys., 82, 70 (1959)

11) Velick, S. F. : J. Biol. Chem., 233, 1455 (1958)

12) Teale, F. W. J. : Biochem. J., 76, 381 (1960)

13) Weber, G. : Biochem. J., 26, 381 (1960)

14) Burton, H. S., Mcweeny, D. J. and Pandhi, P. N. : Nature, 196, 948 (1962)

15) Gomyo, T., Kato, H., Udaka, K., Horikoshi, M. and Fujimaki, M. : Agr. Biol. Chem., 36, 125 (1972)

（昭和 47 年 4 月 13 日受理） 